\title{
The Development of Mortgage Finance in China
}

The Implications of International Experiences

\section{Zhihua Zhou}

\section{(2) OpenEdition}

\section{Journals}

Electronic version

URL: https://journals.openedition.org/chinaperspectives/6862

DOI: $10.4000 /$ chinaperspectives.6862

ISSN: 1996-4617

\section{Publisher}

Centre d'étude français sur la Chine contemporaine

\section{Printed version}

Date of publication: 1 December 2015

Number of pages: 51-61

ISSN: 2070-3449

\section{Electronic reference}

Zhihua Zhou, "The Development of Mortgage Finance in China", China Perspectives [Online], 2015/4 2015, Online since 01 January 2017, connection on 21 September 2021. URL: http://

journals.openedition.org/chinaperspectives/6862; DOI: https://doi.org/10.4000/chinaperspectives 6862

(c) All rights reserved 


\title{
The Development of
}

\section{Mortgage Finance in China}

\author{
The Implications of International Experiences
}

ZHOU ZHIHUA

\begin{abstract}
This paper compares the current Chinese mortgage market with the markets in several advanced economies that suffered most in the 2008 Global Financial Crisis, exploring the potential and rigidities of development of the secondary mortgage market in China. It finds that, first of all, while the over-securitisation of mortgages in the United States accounted for most for its housing decline and subsequent economic stress, the housing downturn in China is largely the result of the underdeveloped housing finance sector. Second, in the absence of a well-functioning legal system and mature primary mortgage market, China needs to make more effort to improve the diversity of the primary market before establishing a secondary market. Third, in China's market transition, the nature of housing should be seen as neither an economic engine, as now in China, nor as a financial derivative, as in the United States.
\end{abstract}

KEYWORDS: housing, finance, mortgage market, GFC, China.

\section{Introduction}

A well-functioning housing finance system will benefit the economy through prosperous real estate development, construction sector employment, more efficient resource allocation, and lower macroeconomic volatility. (1) In particular, as mortgages are essential to enhance buyers' purchasing power and expedite the path to homeownership, many countries have committed to financial innovations creating robust mortgage markets in the past decades. However, the Global Financial Crisis (GFC) around 2008 showed that while innovative financial products can help households achieve the dream of homeownership, they might have adverse effects on the housing and financial sectors and even on the overall economy.

China is transitioning from a socialist central planned economy to a market economy, and both its financial and housing development are still in their early stages. This makes the development of the housing finance system more fundamental and more challenging than in market economies. Along with the flourishing housing development that began in the 1990s, the residential mortgage sector grew rapidly in the 2000s, becoming a financial engine for the housing boom. (2) In September 2014, the Chinese government proposed developing a secondary mortgage market with mortgage-backed securitisation (MBS) ${ }^{(3)}$ to ease the capital shortage problem in the banking system and to reverse the housing downturn that began at the end of 2013. As the global economy remains in the shadow of the GFC triggered by problems in the subprime mortgage markets in the United States, many scholars doubt this strategy and pose several questions: Will MBS development lead to a similar economic crisis in China? Is China ready for the development of a secondary mortgage market under its existing institutions, norms, and regulations? And how is the role of housing justified in the overall socio-economic development?
Updated studies on the Chinese mortgage system, particularly on the secondary market, remain a neglected aspect in the growing English literature on Chinese housing research. This paper tries to fill this gap through a comparative analysis of the current Chinese mortgage market with the markets before or in the early stage of GFC in some advanced economies that had seen the most prosperous development of the mortgage market but suffered most from the GFC. The purpose of the study is to inform market participants and policy-makers in China about the range of mortgage product offerings available in other countries, and to explore the potential and rigidities of development of the secondary mortgage market in China at present state.

\section{The development of housing finance in China}

\section{The restructuring of the housing finance system}

The housing finance system before the 1980 s was simple. Under the central planning regime, the private housing market and residential mortgage lending were absent. Housing was treated as a social welfare product funded

1. Dwight Jaffee, "The U.S. Subprime Mortgage Crisis: Issues Raised and Lessons Learned," World Bank, 2008, available at www-wds.worldbank.org/external/default/WDSContentServer/WDSP/IB/ 2010/12/01/000333038_20101201234552/Rendered/PDF/577270NWPOBox353766B01PUBLIC10gcwp028web.pdf (accessed on 30 December 2014).

2. Deng Yongheng and Fei Peng, "The Emerging Mortgage Markets in China," in Danny Ben-Shahar, Charles Leung and Seow-Eng Ong (eds), Mortgage Market Worldwide, Oxford, Blackwell Publishing, 2008, pp. 1-33.

3. According to Wikipedia, a mortgage-backed security is a type of security that is secured by a mortgage, or more commonly a collection of as many as hundreds of mortgages. The mortgages are sold to a group of individuals (a government agency or investment bank) that "securitises" or lumps the loans together into a security that can be sold to investors. Source: http://en.wikipedia.org/wiki/Mortgage-backed_security (accessed on 31 December 2014). 
and delivered by the government and its agencies (e.g., state-owned enterprises and housing bureaus). This institutional design put huge financial burdens on the government and led to insufficient housing provision nationwide. The average living space per capita decreased from $4.5 \mathrm{~m}^{2}$ in 1952 to $3.6 \mathrm{~m}^{2}$ in 1978, much lower than that in many other countries, e.g. $18 \mathrm{~m}^{2}$ in the United States, $15 \mathrm{~m}^{2}$ in Singapore, $13 \mathrm{~m}^{2}$ in Japan, and $13 \mathrm{~m}^{2}$ in the Soviet Union around 1978. ${ }^{(4)}$

The economic reforms that began in 1978 restructured the housing system by privatising existing welfare housing and introducing a private housing market. The government adopted a variety of strategies to expand funding sources for housing to reduce dependence on the government for housing development. Housing savings banks and the Housing Provident Fund (HPF) were the major innovations in the 1980s and early 1990s.

In October 1987, the first housing savings bank, Yantai Housing Savings Bank, was established in Shandong Province. It was an independent institution established by the local government and several other institutions to provide loan services for developers, investors, builders, and buyers. In May 1988, a second housing savings bank (Bengbu Housing Savings Bank) was established in Anhui Province with a similar function to the Yantai Housing Savings Bank. Loans were provided to account holders at discounted interest rates, and mortgages had a maximum loan-to-value rate of $70 \%$ and maturities of five, ten, and 15 years. (5) However, largely due to the lack of policy support and the prevalence of the HPF, the Bengbu Housing Savings Bank was merged into another bank in 2001 and the Yantai Housing Savings Bank was converted into a normal commercial bank in 2003. In 2004, a third housing savings bank, the Sino-German Bausparkasse Co. Ltd., was set up in Tianjin by China Construction Bank and Bausparkasse Schwaebisch Hall AG with a shareholding of $75.1 \%$ and $24.9 \%$ respectively. By 2013 this bank had provided housing-related products to nearly 110,000 households with a total contract amount of over 40 trillion yuan. ${ }^{(6)}$

Modelled on the Central Provident Fund in Singapore, China's HPF debuted as an experiment in Shanghai in 1991 and became an official national strategy in 1995. The HPF is a program in which both employers and employees of public and private enterprises are required to contribute a certain percentage of the employees' salaries, normally $5 \%$, to employees' HPF accounts with the China Construction Bank. Employees can use the HPF to purchase homes in the private market or for housing repairs and construction. A specialised entity under the supervision of the municipal government, the Housing Provident Fund Management Centre, is responsible for managing the HPF.

The mortgage market did not play an important role until the mid-1990s. As most housing purchases before the mid-1990s resulted from the sale of welfare housing to sitting tenants by their employers (state-owned enterprises) at low prices, there was generally little need for a mortgage. Meanwhile, the state-owned banks were not comfortable with providing loans to individuals and often imposed harsh restrictions on loan originations. Loans prior to the 1990s were available only to those who had bank savings equal to $30 \%$ of the home's value, with loan maturity of up to five years. ${ }^{(7)}$ In 1997, mortgage loans represented only $12.7 \%$ of total real estate loans. ${ }^{(8)}$ Most real estate loans went to the supply side to finance the construction of new buildings, partially contributing to the oversupply of commercial housing, the bankruptcy of many development companies, and the demolition of properties in some regions in the early- and mid-1990s.

The turning point came with the termination of welfare housing provision in 1998. The central bank set up basic mortgage lending standards to support housing purchases by households in the private market. Banks wel- comed residential mortgage lending, since the default rate for individual mortgage loans was generally lower than for state-owned enterprises. ${ }^{(9)}$ The establishment of lending standards and the changing attitude of banks, coupled with strong housing demand following the termination of welfare housing, led to unprecedented growth in the housing and mortgage markets in subsequent years. The ratio of real estate investment to GDP increased from $4.28 \%$ in 1998 to $15.12 \%$ in 2013 , and national housing price increased from 2,063 yuan $/ \mathrm{m}^{2}$ in 1998 to $6,237 \mathrm{yuan} / \mathrm{m}^{2}$ in 2013 . The number of enterprises engaged in the real estate sector increased from 24,378 in 1998 to 91,444 in 2013. The per capita floor area in the urban areas increased from $8.8 \mathrm{~m}^{2}$ in 1998 to $32.9 \mathrm{~m}^{2}$ in 2012. The balance of mortgage loans amounted to 11.12 trillion yuan as of September 2014, up from 42.62 billion yuan in 1998. ${ }^{(10)}$

It is notable that administrative measures and monetary policies have been among the most critical deterrents to housing and mortgage development in the past two decades. For example, the government set housing as the pillar industry to sustain economic growth around the 1997 Asian Financial Crisis. As a result, mortgage loans recorded a year-on-year increase of $87.8 \%$ in 1999. (11) The central bank adjusted the interest rates four times and the deposit reserve ratio twice in the fourth quarter of 2008 to prop up the housing downturn caused by the GFC. In 2011, the central government put restrictive administrative policies on housing purchases and mortgage borrowings to cool the overheated housing market (e.g., some citizens are not allowed to purchase housing units or apply for mortgages). Legislated as the sole owner of urban land by the Constitution, the government serves as the supplier of urban land and played a market role in the housing market.

\section{The mortgage market in China}

\section{The primary market}

Housing financial institutions: Two kinds of housing finance institutions operate in China, including general finance institutions and specialist housing finance institutions (see Figure 1). The former plays a much bigger role than the latter in the mortgage market. In particular, the five state-owned commercial banks dominate the mortgage market, as evident from their high market shares in Table 1. These five banks, previously state-owned, listed on the stock exchange in the 2000s and became responsible for their business operations under the strict supervision of the central bank. In addition, there were 12 joint-equity commercial banks, 116 city commercial banks, 48 foreign commercial banks and hundreds of rural financial institutions as of December 2014. (12)

4. Zhang Xianqiao, "Taolun chengshi zhuzhai wenti" (Discussing the Issue of Urban Residential Housing), Tianjin Social Science, Vol. 6, 1984, pp. 23-28.

5. Gao Shangquan and Chu Chuanheng (eds), "Zhongguo chengzhen zhufang zhidu gaige quanshu" (Complete Collection on Housing System Reform in Chinese Cities and Towns), Beijing, China jihua Press, 1996.

6. China Construction Bank, "Sino-German Bausparkasse Co. Ltd.," (Zhongde zhufang chuxu yinhang youxian zeren gongsi), 2014, www.ccb.com/cn/public/20100126_1264493340.html (accessed on 30 December 2014).

7. Zhang Xinquan, "The Restructuring of the Housing Finance System in Urban China," Cities, Vol. 17, No. 5, 2000, pp. 339-348.

8. China Statistical Yearbook, Beijing, China Statistical Press, 1998.

9. Deng Yongheng and Fei Peng, "The Emerging Mortgage Markets in China," art. cit.

10. China Statistical Yearbook, Beijing, China Statistical Press, 2014.

11. China Statistical Yearbook, Beijing, China Statistical Press, 2000.

12. China Banking Regulatory Commission, "The Structure of Financial Institutions in China," 2014, www.cbrc.gov.cn/showyjhjjindex.do (accessed on 30 December 2014). 


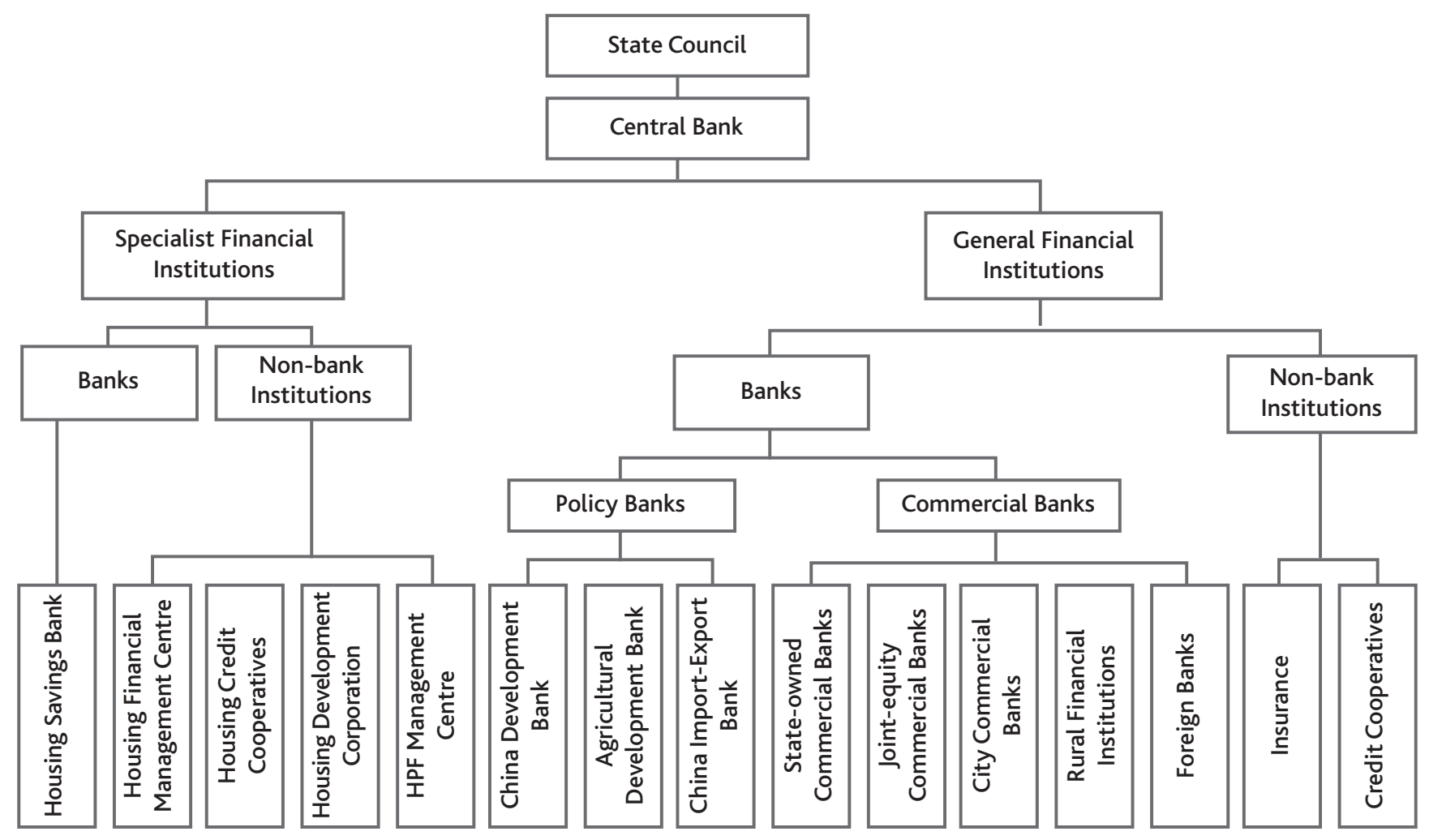

Note:The state-owned commercial banks include the Industry and Business Bank of China, the Agricultural Bank of China, the Bank of China, the Construction Bank of China, and the Transportation Bank of China. The 12 joint-equity commercial banks include CITIC Industrial Bank, China Everbright Bank, Hua Xia Bank, China Minsheng Banking Corporation, China Merchant Bank, Industrial Bank Co., Ltd, Guangdong Development Bank, Ping An Bank Co., Ltd, Shanghai Pudong Development Bank, Evergrowing Bank Co. Ltd, China Zheshang Bank Co. Ltd, Bohai Bank.

Source: compiled by the author. Data source: China Banking Regulatory Commission, "The Structure of Financial Institutions in China," 2014, www.cbrc.gov.cn/showyjhjjindex.do (accessed on 30 December 2014).

Housing financial instruments: Mortgages in the primary market include commercial individual loans and HPF loans. As the HPF loans have amount ceilings and in many cases are not enough to complete transactions due to high housing prices, hybrid mortgages that combine the maximum amount of HPF and commercial mortgages were introduced. Commercial mortgage loans have dominated the mortgage market. The balance of HPF loans was $19.22 \%$ of the total balance of commercial mortgage loans as of December 2014. ${ }^{(13)}$

Interest rate and maturity: All residential mortgages in China are adjustable rate mortgages, following the baseline set by the central bank. Once the central bank announces a rate adjustment, it is applied to all existing mortgage loans with maturity greater than one year starting from the beginning of the following year. Since 2005, commercial banks have been allowed to adjust the mortgage rates for their business operations. As of December 2014, the market shares of domestic bank loans with interest rates at lower, flat, and over the baseline were $13.10 \%, 19.64 \%$ and $67.26 \%$ respectively. ${ }^{(14)}$ The HPF interest rate is much lower than that of commercial mortgages. The over-five-year interest rates for commercial mortgage loans and HPF were $6.55 \%$ and $4.50 \%$ respectively as of December 2013. ${ }^{(15)}$ The minimum down payment is set by the central bank at $20 \%$, the maximum mortgage maturity is 30 years, and the applicant's age plus mortgage length should not exceed 65 years.
Default rate: The default rate in China is relatively low (see Table 1). Most default cases in the real estate sector are related to presale properties where the developers failed to deliver housing units on time or to meet the conditions in the contracts. The low default rate is largely the result of bank due diligence procedures that carefully ascertain the applicants' income, occupation, and asset status, etc. Applicants must provide documents including tax returns, bank statements, and proof of other assets, e.g., vehicle ownership, stock investments, and ownership of other properties. Banks may require additional guarantees and commercial insurance. The bank headquarters actively monitor the delinquency rates in their mortgage portfolios from time to time. ${ }^{(16)}$

13. Zhonghua renmin gongheguo zhufang he chengxiang jianshe bu (Ministry of Housing and Urbanrural Development), "Quanguo zhufang gongijiin 2014 nian niandu baogao" (2014 Annual Report on National Housing Provident Fund System), www.mohurd.gov.cn/zcfg/jsbwj_0/zfbzyg jjjdgls/201506/t20150612_221380.html (accessed on 3 October 2015).

14. Zhongguo renmin yinhang huobi zhengce fenxi xiaozu (Central Bank), "Zhongguo huobi zhengce zhixing baogao. Erlingyisi nian di si jidu" (Report on the Performance of Monetary Policies: $4^{\text {th }}$ Quarter 2014), www.gov.cn/foot/site1/20150210/48111423567940903.pdf (accessed on 3 October 2015).

15. Central bank, "Benchmark Interest Rate of Financial Institutions," 2014, www.pbc.gov.cn/publish/ zhengcehuobisi/629/2012/20120706182054758117206/20120706182054758117206_html, (accessed on 30 December 2014).

16. Deng Yongheng and Peng Liu, "Mortgage Prepayment and Default Behavior with Embedded Forward Contract Risks in China's Housing Market," Journal of Real Estate Finance Economics, Vol. 38 , No. 3, 2009, pp. 214-240. 
Table 1 - Market share of housing finance institutions in China, Q3 2014 (billion yuan, \%)

\begin{tabular}{|c|c|c|c|}
\hline Bank Types & Total Assets & Total Loan Balance & Non-Performing Loans to Total \\
\hline Commercial Banks & $66,879.2$ & 427.2 & 1.12 \\
\hline Joint-equity Commercial Banks & $29,710.6$ & 152.7 & 1.09 \\
\hline City Commercial Banks & $17,099.9$ & 78.6 & 1.11 \\
\hline Rural Financial Institutions & $21,488.6$ & 100.2 & 1.86 \\
\hline Foreign Banks & $2,580.5$ & 81.0 & 0.69 \\
\hline
\end{tabular}

Source: China Banking Regulatory Commission, "Market share of housing finance institutions in China, Q3 2014," 2014, www.cbrc.gov.cn/showyjhjjindex.do (accessed on 30 December 2014).

Table 2 - Balance sheet of credit funds of financial institutions in China

\begin{tabular}{|l|c|c|}
\hline & 2013 (billion yuan) & 100 \\
\hline Total & $117,466.6$ & 88.86 \\
\hline 1) Total Deposits & $104,384.7$ & 49.89 \\
Corporate deposits & $52,082.6$ & 44.70 \\
Personal deposits & $46,650.2$ & 2.89 \\
\hline Fiscal deposits & $3,013.3$ & 0.16 \\
\hline Temporary deposits & 166.1 & 0.03 \\
\hline Designated deposits & 35.4 & 2.33 \\
\hline Other deposits & $2,437.0$ & 0.57 \\
\hline 2) Financial Bond & 668.1 & 5.00 \\
\hline 3) Currency in Circulation & $5,857.4$ & 0.07 \\
\hline 4) Liabilities to International Financial Institutions & 85.4 & 5.51 \\
\hline 5) Others & $6,470.9$ & \\
\hline
\end{tabular}

Source: China Statistical Yearbook, Beijing, China Statistical Press, 2014.

Prepayment penalty: The prepayment penalty compensates the lender for reinvestment risk and for the cost of processing the prepayment. Despite the popularity of prepayment, there is no penalty on prepayment in China. While changes in household income and interest rates for deposits are the determinants driving mortgage prepayments, the most sensitive factor could be fluctuations in mortgage interest rates. Moreover, as individuals in China have limited alternative investment opportunities, many applicants choose to pay off mortgages in a depressed stock market.

Funding sources: Through the restructuring of the housing finance system, the government has withdrawn from the budgetary funding mechanism for housing provision, and general financial institutions have become the main funding providers for housing purchases by individuals. Table 2 shows that deposits were the major funding source of loans for general financial institutions in 2013.

\section{The secondary market}

With the rapid growth of residential mortgages in China, the commercial banks are eager to improve the liquidity of mortgage loans. However, they have limited alternatives to liquidate their mortgage products in the capital market. The central bank set up a pilot for MBS in 2005, under which China
Construction Bank was authorised to issue a MBS deal of 3.0 billion yuan in the domestic interbank bond market. China Construction Bank issued another MBS deal of 4.0 billion yuan in 2007. However, MBS development was halted largely due to the GFC triggered by problems with MBS in the United States. It was not until July 2014 that the Postal Savings Bank of China announced the third MBS of 6.8 billion yuan. In September 2014, the central bank released a policy document encouraging banking organisations to commit to the development of MBS and other financial bonds with longterm maturities to raise capital exclusively for mortgages, particularly for first-home buyers of self-occupied premises.

The resumption of MBS was largely due to the downturn in the housing market that began in late 2013. The amount of floor space and total sales of commercial buildings sold between January and September 2014 both declined from those in 2013 by $8.6 \%$ and $8.9 \%$, respectively. ${ }^{(17)}$ Several factors contributed to this market downturn, including large-scale housing inventory in some cities, the ongoing massive social housing programme, the expected property tax levy, the recent anti-corruption

17. Zhonghua renmin gongheguo guojia tongjiju (National Bureau of Statistics), "2014 nian 1-9 yuefen quanguo fangdichan kaifa he xiaoshou qingkuang" (National Real Estate Investment and Market Performance: January-September 2014), 2014, www.stats.gov.cn/tjsj/zxfb/201410/t20 141021_626821.html (accessed on 30 December 2014). 
Table 3 - Statistical report on the loans of financial institutes: Q1 2014 (trillion yuan, \%)

\begin{tabular}{|c|c|c|c|}
\hline Item & Date & Year-on-year increase & Growth Rate of year-on-year increase \\
\hline Balance of RMB deposits & 109.10 & 11.4 & -4.2 \\
\hline Balance of bank loans & 74.91 & 13.9 & -0.2 \\
\hline Balance of real estate loans & 15.42 & 18.8 & -0.3 \\
\hline Balance of individual mortgage loans & 10.29 & 20.1 & -0.9 \\
\hline
\end{tabular}

Source: Zhongguo renmin yinhang (Central Bank of the PRC), "2014 nian yi jidu jinrong jigou daikuan touxiang tongji baogao" (Statistical Report on the Loans of Financial Institutions: Q1 2014), 2014, www.pbc.gov.cn/goutongjiaoliu/113456/113469/2806335/index.html (accessed on 29 November 2015).

\section{Table 4 - Growth rates of capital adequacy ratio and business profits of state-owned commercial banks (\%)}

\begin{tabular}{|l|c|c|c|c|}
\hline \multicolumn{1}{|c|}{ Bank } & \multicolumn{2}{c|}{ Capital Adequacy Ratio } & \multicolumn{2}{c|}{ Business Profit } \\
& 2012 & 2013 & 2012 & 1013 \\
\hline Industrial and Commercial Bank of China & 13.66 & 13.12 & 14.51 & 14.52 \\
\hline Agricultural Bank of China & 12.61 & 11.86 & 19.00 & 12.35 \\
\hline Bank of China & 13.63 & 12.46 & 11.67 & 11.12 \\
\hline China Construction Bank & 14.32 & 13.34 & 14.26 & 6.82 \\
\hline Bank of Communication China & 14.07 & 12.08 & 15.05 & \\
\hline
\end{tabular}

Note: According to Wikipedia, the capital adequacy ratio (CAR) is the ratio of a bank's capital to its risk. National regulators track a bank's CAR to ensure that it can absorb a reasonable amount of loss and that it complies with statutory capital requirements.

Source: Zhongguo renmin yinhang (Central Bank of the PRC), "2013 nian di yi jidu Zhongguo huobi zhengce zhixing baogao" (Report of Chinese Monetary Policy Performance: Q1 2013), www.pbc.gov.cn/zhengcehuobisi/125207/125227/125957/125991/2892009/index.html; "2014 nian di yi jidu Zhongguo huobi zhengce zhixing baogao" (Report of Chinese Monetary Policy Performance: Q1 2014), p.14, www.pbc.gov.cn/zhengcehuobisi/125207/125227/125957/125988/2806502/index.html (both accessed on 29 November 2015).

campaign, and most significantly, the capital shortage in the real estate sector. The rise of Internet finance and the flourishing of the shadow banking system around 2013 have greatly reduced the capital of commercial banks. The balances of deposits declined quarter-to-quarter and month-to-month in the first quarter of 2014 (see Table 3). Four out of the five state-owned commercial banks recorded lower year-on-year profit growth rates in 2013 (see Table 4). With reduced capital and the slowdown in profit growth, the commercial banks strategically controlled capital flow to the real estate sector. Particularly, banks showed less interest in individual mortgage loans, which were generally safe but of low profit due to their long maturity and relatively low interest rates compared with short-term loans to small and medium private enterprises. Many banks initiated strict rules on mortgage applications and increased mortgage interest rates by $5 \%-15 \%$ and down payments from $60 \%$ to $70 \%$ for second housing unit purchases. Consequently, the growth rates in real estate loans recorded a year-on-year decrease of $0.3 \%$ in the first quarter of 2014 (see Table 3). The growth of developers' capital in hand slowed considerably from 28.7\% in September 2013 to 2.3\% in September 2014. While bank loans were reduced, developers, most with high liability-to-asset ratios of around 75\%, (18) dropped housing prices for faster capital return.

Overall, a mortgage market has been gradually taking shape since the 1990s to match the prosperous housing development. The mortgage market has grown rapidly, and individual mortgages represented $61.64 \%$ of the total real estate loans in 2013, upon from $13.72 \%$ in 1998 (see Table 5), implying the shift in focus of housing finance from the supply sector in the 1990 s to the consumption side in the 2000s. The mortgage market is dominated by the five state-owned commercial banks with adjustable interest rates set by the central bank. The fund sources for mortgages are very limited, and a secondary market has not emerged in China. As a result of the legacy of socialist central planning, government involvement in the mortgage market is particularly strong, and there are strong ties between the central government and the central bank, and between the central bank and the commercial banks.

\section{Comparing the Mortgage Markets}

\section{Diversity in mortgage markets}

While the residential mortgage market in China is still in its early stage, advanced economies generally had relatively large mortgage markets before or around the GFC, with a variety of configurations in the market share of adjustable- versus fixed-rate mortgages, and choices of prepayment penalties, mortgage maturity, funding mechanisms (deposits versus capital markets), etc.

Mortgage interest rates and maturity: There were considerable differences in mortgage offerings in terms of interest rates and maturity across the case countries. The market shares of various interest rates varied across economies around 2009. Australia, Ireland, Korea, and Spain adopted the standard adjustable-rate mortgage, under which the rate was set by the lenders at their discretion and might vary across borrowers. Short and medium-term fixed-rate mortgages were the dominant instrument in Canada, the Netherlands, and Switzerland. These instruments were rollover

18. China Statistical Yearbook, Beijing, China Statistical Press, 2014. 


\section{Table 5 - The development of the primary mortgage market in China (billion yuan, \%)}

\begin{tabular}{|c|c|c|}
\hline & 1998 & 2013 \\
\hline Real estate investment & 361.42 & $8,601.30$ \\
\% of total fixed asset investment & 12.72 & 19.24 \\
\% of GDP & 4.28 & 15.12 \\
\hline Housing investment & 208.16 & $5,895.10$ \\
\hline \% of total real estate investment & 57.60 & 68.5 \\
\hline Balance of real estate loans & 310.62 & $14,600.0$ \\
\hline \% of total bank loans & 3.6 & 21.0 \\
\hline Balance of individual mortgage loans & 42.62 & $9,800.0$ \\
\hline of total real estate loans & 13.72 & 61.64 \\
\hline of GDP & 0.5 & 17.2 \\
\hline
\end{tabular}

Source: China Statistical Yearbook, Beijing, China Statistical Press, 1999 and 2014; Zhongguo renmin yinhang (Central Bank of the PRC), "2014 nian jinrong jigou daikuan touxiang tongji baogao" (Statistical Report on the Loans of Financial Institutions 2014), 2015, www.pbc.gov.cn/diaochatongjisi/116219/116225/2810329/index.html (accessed on 29 November 2015).

or renegotiable rate loans in which the rate was typically fixed for a period of up to five years with a longer amortisation period. Fixed mortgage interest rates of over five years were rare, except for mortgages in Germany, which could be fixed for up to 15 years with a 30-year amortisation. France was the only European country dominated by fixed-rate mortgages. The mortgage market in the United States was unusual because of the prevalence of long-term fixed-rate mortgages with interest rates fixed for 30 years.

Typical maturity in the eurozone before the GFC was 20 to 30 years. ${ }^{(19)}$ Longer maturity products existed in several countries, with up to 50 years in Spain and France and up to 60 years in Finland, although with low market shares. At an extreme, Switzerland had 100-year (inter-generational) mortgages. As in China, the maximum maturity was often linked to retirement age.

Prepayment penalty: While China does not apply the prepayment penalty, many countries used penalties to compensate the lender for lost interest over the remaining term of the fixed rate (see Table 6). Prepayment penalties on fixed-rate mortgages were not allowed in many states in United States. Even in states that allowed them, Fannie Mae and Freddie Mac historically did not enforce such penalties. Prepayment penalties were sometimes restricted to certain conditions, for instance, in Germany if the borrower was moving out or if the lender refused a request to increase the mortgage. (20)

Mortgage default rates: As shown in Table 1, China has a low mortgage default rate. While many countries saw greater house price volatility compared with the United States, households faced lower levels of negative equity and lower default rates than their counterparts in the United States. ${ }^{(21)}$ Delinquencies on securitised loans in many countries increased, but remained well below those in the United States. Spain and the United Kingdom also saw a substantial increase in mortgage defaults during the crisis, but to a much lesser extent than in the United States. In the United States, housing defaults reached their highest level since the 1930s, and 11.1 million residential properties (23.1\% of the total) had negative equity mortgages in 2010. (22)
Funding sources for mortgages: Banks in many countries play a major role in originating mortgage loans, and their financing resources differ substantially across countries. The bank can swap its short-term deposits for medium maturity fixed-rate liabilities; it can issue medium-term fixed-rate debt by covered bond, a securitisation scheme in which bonds backed by selected mortgages pooled by lenders are sold to investors through the secondary market (bond market); and mortgage securitisation is an alternative in which securities backed by selected mortgages pooled by lenders are sold to investors through the secondary market (securities market). The biggest difference between covered bonds and mortgage-backed securities is that while mortgage-backed securities are off the issuer's balance sheet once sold, covered bonds remain obligations of the issuer (often a bank), and the assets remain on the issuer's balance sheet (usually with an appropriate capital charge); in essence, the investor has recourse against the issuer and the collateral. In many countries deposits were the fundamental sources for mortgages, and the role of covered bonds and MBS were still limited. (23) Many European countries favoured the covered bond to finance mortgages, and the outstanding value of mortgage-covered bonds in the eurozone rose by almost $80 \%$ between 2003 and 2007. (24) Covered bonds accounted for more than half of the residential loans in Spain and Sweden in 2008. Denmark was notable, with covered bonds accounting for $100 \%$ of residential loans outstanding.

The United States securitised more than $60 \%$ of mortgages to government-sponsored enterprises or the market. Compared to covered bonds, mortgage securitisation had a cost advantage due to smaller capital requirements. Also, the Federal Deposit Insurance Corporation was unhappy

19. Michael Lea, "International Comparison of Mortgage Product Offerings," Research Institute for Housing America, 2010, www.housingamerica.org/RIHA/RIHA/Publications/74023_10122_Research_RIHA_Lea_Report.pdf (accessed on 30 December 2014).

20. Ibid.

21. Ibid.

22. IMF, "Global Financial Stability Report 2011," 2011, www.imf.org/external/pubs/ft/gfsr/2011/01 (accessed on 30 December 2014).

23. Michael Lea, "International Comparison of Mortgage Product Offerings," Research Institute for Housing America, op. cit.

24. European Central Bank, "Housing Finance in the Euro Area, March 2009," 2009, www.ecb .europa.eu/pub/pdf/other/housingfinanceeuroarea0309en.pdf (accessed on 30 December 2014). 
Table 6 - Prepayment penalties in selected countries

\begin{tabular}{|c|c|c|c|}
\hline Country & Amount & Applicability & Penalty Free Payment \\
\hline Denmark & Yield maintenance & $\begin{array}{l}\text { Short-term fixed: loans } \\
\text { with non-callable bonds }\end{array}$ & \\
\hline Germany & $\begin{array}{l}\text { Interest margin damage } \\
\text { and reinvestment loss }\end{array}$ & $\begin{array}{l}\text { All fixed rate; no penalty on adjustable rate; } \\
\text { maximum } 10 \text { year }\end{array}$ & No penalty if property sold \\
\hline Spain & $\begin{array}{l}2.5 \% \text { up to yield maintenance; } \\
0.5 \%\end{array}$ & $\begin{array}{c}\text { Fixed rate; } \\
\text { Adjustable rate }\end{array}$ & Maximum $10 \%$ per year \\
\hline France & $\begin{array}{l}\text { Maximum } 6 \text { months interest or } \\
3 \% \text { of outstanding balance }\end{array}$ & Adjustable or fixed rate & $\begin{array}{l}\text { No fee in case of unemployment, death, } \\
\text { or job change }\end{array}$ \\
\hline Netherlands & Yield maintenance & Fixed rate & $\begin{array}{l}10 \% \text { per year, hardship or relocation } \\
\text { with no penalty }\end{array}$ \\
\hline UK & $2-5 \%$ of amount repaid & $\begin{array}{l}\text { Discounts and fixed rate; in contrast } \\
\text { roughly } 3 \text { monthly payments }\end{array}$ & \\
\hline Canada & Higher of lost interest or 3 months & Lender may waive for own customer & Up to $20 \%$ per year \\
\hline Australia & Change in cost of funds & Discounts and fixed rates; in contact & \\
\hline US & Up to $5 \%$; more typically $3 \%$ & Adjustable rate & $20 \%$ \\
\hline Switzerland & Yield maintenance & Fixed rate & \\
\hline
\end{tabular}

Source: Michael Lea, "International Comparison of Mortgage Product Offerings," Research Institute for Housing America, 2010, www.housingamerica.org/RIHA/RIHA/Publications/74023_10122_Research_RIHA_Lea_Report.pdf (accessed on 30 December 2014).

about the use of covered bonds as they create a class of claimants in liquidation. The presence of the government-backed secondary mortgage market institutions that lowered the price of such mortgages enabled the dominance of the fixed rate long-term mortgage loans in the United States. These securities did provide higher-than-normal yields when the housing market continued to climb. However, when housing prices started to drop around 2007, elevated default rates among subprime mortgage loans triggered the credit crunch through losses on these securities in the global financial markets, and dramatically reduced liquidity in the system. Moreover, compared with covered bonds, mortgage securitisation had a cost advantage due to smaller capital requirements. ${ }^{(25)}$ The Federal Deposit Insurance Corporation (FDIC) was also unhappy with the use of covered bonds as they create a class of claimants in liquidation. (26) The presence of governmentbacked secondary mortgage market institutions that lowered the price of such mortgages enabled the dominance of fixed rate long-term mortgage loans in the United States. These securities provided higher-than-normal yields while the housing market continued to climb, but when housing prices began to drop around 2007, elevated default rates among subprime mortgage loans triggered the credit crunch through losses on these securities in the global financial markets, and dramatically reduced liquidity in the system. ${ }^{(27)}$

\section{Degree of government involvement in the mortgage market}

Unlike government intervention via administrative measures and monetary policies in China, government involvement in the market economies mainly included state-owned financial institutions that originated mortgage loans and state-sponsored housing finance agencies that provided liquidity facilities for the mortgage markets, along with homeownership promotion for the poor and disadvantaged, and the improvement of the legal framework for the mortgage market.

Housing finance agencies: There were significant differences among countries in the presence of government support for mortgage markets, mainly including insurance guarantees of mortgages, guarantees of securitised mortgages, and institutional support via government-sponsored entities. Canada and the Netherlands had government-backed mortgage insurance programs. The German Development Bank provided mortgage subsidies to commercial banks for purchases of energy-efficient housing and other socially desirable purposes (e.g., homes for the elderly). However, no European countries provided all three pillars offered in the United States. The market share of mortgages backed by government entities in the United States was larger than that in any European advanced economies. (28)

Homeownership promotion: In the mid-1950s, the homeownership rate in the United States had already reached $60 \%$, higher than that in many

25. Ben Bernanke, "The Crisis and the Policy Response," 2009, Board of Governors of the Federal Reserve System, http://www.federalreserve.gov/newsevents/speech/bernanke20090113a.htm (accessed on 30 December 2014).

26. Michael Lea, "International Comparison of Mortgage Product Offerings," Research Institute for Housing America, op. cit.

27. Paul Mizen, "The Credit Crunch of 2007-2008: A Discussion of the Background, Market Reactions, and Policy Responses," Federal Reserve Bank of St. Louis Review, Vol. 90, No. 5, 2008, pp. 531-567.

28. Michael Lea, "International Comparison of Mortgage Product Offerings," op. cit. 


\section{Table 7 - Housing finance systems in selected countries around 2008 and China in 2014}

\begin{tabular}{|c|c|c|c|c|c|c|}
\hline \multirow[b]{2}{*}{ Economy } & \multirow[b]{2}{*}{ Main Lenders } & \multicolumn{3}{|c|}{ Mortgage Funding } & \multicolumn{2}{|c|}{ Mortgage Loan Features } \\
\hline & & Deposits & $\begin{array}{c}\text { Covered } \\
\text { bond/residential } \\
\text { loans (\%) }\end{array}$ & $\begin{array}{l}\text { MBS/residential } \\
\text { loans (\%) }\end{array}$ & $\begin{array}{l}\text { Predominant } \\
\text { interest rate type }\end{array}$ & $\begin{array}{c}\text { Maximum } \\
\text { loan-to-value on } \\
\text { mortgage loans }\end{array}$ \\
\hline Austria & Banks and saving banks & Mainly & 7.0 & 3.1 & Fixed & 80 \\
\hline Belgium & Banks & Mainly & & 29.9 & Fixed & 100 \\
\hline Canada & $\begin{array}{c}\text { Banks and specialised non-depository } \\
\text { and mortgage brokers }\end{array}$ & $\begin{array}{c}\text { Mainly (banks); } \\
\text { securitisation } \\
\text { (non-banks) }\end{array}$ & 1.0 & 31.0 & Mixed & $80(95)$ \\
\hline Denmark & Mortgage and retails banks & & 114.7 & 0.1 & Mixed & 80 \\
\hline France & Mortgage and retails banks & Mainly (banks) & 22.5 & 1.8 & Fixed & 100 \\
\hline Germany & Banks and saving banks & & 19.0 & 1.8 & Fixed & 80 \\
\hline Ireland & Bank and building societies and mortgage brokers & Mainly (banks) & 15.6 & 29.6 & Variable & $100+$ \\
\hline Italy & Banks & Mainly & 2.1 & 30.8 & Mixed & 80 \\
\hline Netherlands & Banks and mortgage banks and brokers & Mainly & 3.6 & 30.8 & Fixed & 125 \\
\hline Portugal & Banks & & 14.5 & 27.3 & Variable & 90 \\
\hline Spain & $\begin{array}{l}\text { Banks (commercial and savings) } \\
\text { and mortgage brokers }\end{array}$ & $\begin{array}{c}\text { Some, plus } \\
\text { covered bonds } \\
\text { and securitisation }\end{array}$ & 45.6 & 24.1 & Variable & 100 \\
\hline Sweden & Bank and mortgage institutions & $\begin{array}{l}\text { Some, plus } \\
\text { covered bonds }\end{array}$ & 53.7 & 0.3 & Variable & $80-95$ \\
\hline UK & Bank and building societies and mortgage brokers & Mainly & 14.0 & 31.2 & Variable & 110 \\
\hline US & Banks and mortgage brokers & $\begin{array}{c}\text { Mainly } \\
\text { securitisation }\end{array}$ & 0.1 & 64.1 & Fixed & $100+$ \\
\hline China & Banks & Largely & & & Variable & 80 \\
\hline
\end{tabular}

* There is a complete waiver in certain circumstances, for instance, if the property is sold (Germany), hardship or relocation of the borrower (Netherlands), or the borrower is unemployed (France).

Source: compiled by the author, data source: IMF, "Global Financial Stability Report 2011," www.imf.org/external/pubs/ft/gfsr/2011/01 (accessed on 30 December 2014); Michael Lea, "International Comparison of Mortgage Product Offerings," Research Institute for Housing America, 2010,

www.housingamerica.org/RIHA/RIHA/Publications/74023_10122_Research_RIHA_Lea_Report.pdf (accessed on 30 December 2014); China Statistical Yearbook, Beijing, China Statistical Press, 2014

European countries, e.g., 33\% for France, 13\% for Germany, 26\% for Sweden, and 43\% for the United Kingdom. ${ }^{(29)}$ In 2008, the homeownership rate in the United States was similar to the rates of many European countries. ${ }^{(30)}$ This is noteworthy, as these European countries provided far less government support for homeownership than the United States did. For instance, while some European countries provided full or partial deduction of mortgage interest payments, particularly for owner-occupied housing, the United States provided very beneficial tax treatment and allowed full tax deductibility for the payment of mortgage interest. This implies that there is no positive relation between homeownership rates and the degree of government involvement. High homeownership in China is largely the result of the privatisation of welfare housing rather than of the wealth accumulation or government support as seen in the case countries. Nevertheless, the Chinese government has given the ownership market priority over the rental market since the termination of wealth housing provision in 1998, as the former brings huge amounts of fiscal income from taxes on housing transactions and land sales.

Supervisory and regulatory structures: The key determinants of the market depth of mortgage finance in advanced economies are collateral and

29. Michael Haines and Allen Goodman, "A Home of One's Own: Aging and Homeownership in the United States in the late Nineteenth and Early Twentieth Centuries," NBER Historical Working Paper No. 21, NBER Program, January 1991.

30. The exceptional case of low homeownership in Germany is in part due to government incentives for rental housing. Switzerland has historically had a low homeownership rate, reflecting the high cost of housing and a large foreign-born (often transient) population. Southern European countries such as Italy, Greece, and Spain have higher rates of homeownership, largely because of their cultural values and discriminatory policies towards private rental housing and weaker support of social rental housing. 


\begin{tabular}{|c|c|c|c|}
\hline & Mortgage Loan Features & \multirow{2}{*}{$\begin{array}{c}\text { Mortgage } \\
\text { Indebtedness }\end{array}$} & \multirow{2}{*}{$\begin{array}{l}\text { Home- } \\
\text { ownership }\end{array}$} \\
\hline $\begin{array}{c}\text { Typical } \\
\text { loan maturity } \\
\text { (years) }\end{array}$ & $\begin{array}{l}\text { Prepayment } \\
\text { penalties* }\end{array}$ & & \\
\hline $25-30$ & & 28 & 58 \\
\hline 20 & & 46 & 78 \\
\hline $25-35$ & $\begin{array}{l}\text { Higher of lost interest or three } \\
\text { months, beyond a pre-specified } \\
\text { penalty-free limit }\end{array}$ & & 66 \\
\hline 30 & $\begin{array}{l}\text { Yield maintenance } \\
\text { on short-term fixed } \\
\text { with non-callable bonds }\end{array}$ & 101 & 54 \\
\hline $15-20$ & $\begin{array}{l}\text { Maximum six months interest } \\
\text { or } 3 \% \text { of outstanding balance }\end{array}$ & 41 & 58 \\
\hline $20-30$ & $\begin{array}{l}\text { Interest margin damage and } \\
\text { reinvestment loss on fixed rate }\end{array}$ & 47 & 43 \\
\hline $21-35$ & & 87 & 75 \\
\hline 20 & & 23 & 80 \\
\hline 30 & Yield maintenance on fixed rate & 107 & 56 \\
\hline $25-35$ & & 66 & 75 \\
\hline 30 & $\begin{array}{l}2.5 \% \text { up to yield maintenance } \\
\text { on fixed rate, } 0.5 \% \text { on variable } \\
\text { rate }\end{array}$ & 64 & 85 \\
\hline $30-45$ & & 82 & 66 \\
\hline 25 & $2-5 \%$ of amount repaid & 85 & 66 \\
\hline 30 & Up to $5 \%$ on ARMs only & 81 & 67 \\
\hline $20-30$ & & 17 & 82 \\
\hline
\end{tabular}

bankruptcy laws that define the legal rights of borrowers and lenders. ${ }^{(31)} \mathrm{A}$ well-functioning regulatory system is necessary to ensure the transparency of information on financing costs and housing transactions, helping appraisers value house purchases for interested parties and allowing lenders to gauge default probabilities and track the value of their collateral. (32) While European countries had stringent oversight and banks maintained mortgages on their balance sheets, underwriters in the United States relied on government standards with simple screening tools that lacked means to evaluate the likelihood of repayment, then sold mortgages to government-sponsored enterprises and had no further interest in the mortgage after sale. Most European countries had a single financial sector regulator who oversaw the banking and capital markets, but the United States had a relatively fragmented regulatory structure, with mortgage lenders regulated by multiple authorities depending on the type of financial institution. Liberal regulation in the United States with respect to new financial innovations, especially derivatives, resulted in a high degree of mortgage securitisation. This indicates that a well-functioning legal and regulatory framework is crucial, particularly for a viable mortgage securitisation market, e.g., functioning bankruptcy laws, clarity as to mortgage loan transfer procedures, and reliable issuer-investor dispute resolution mechanisms. In China, however, such frameworks for the newly emerged mortgage market are still under construction.

\section{Correlations between the mortgage market, housing prices, and economic stability}

Housing price movements paralleled the size of mortgage markets in many advanced economies before and around the GFC. Relaxing lending standards in good times drives up house prices, while a tightening of standards puts downward pressure on house prices. (33) Many advanced economies witnessed strong growth in mortgage loans along with their unprecedented run-up in housing prices before the crisis. (34) By 2009, many countries had already recorded large mortgage markets, and the ratio of mortgage debt to GDP in 2009 was $82 \%, 82 \%$, and $85 \%$ in Sweden, the United States, and the United Kingdom respectively. Notably, Denmark, the Netherlands and Switzerland recorded ratios of over $100 \%$. ${ }^{(35)}$ Higher loanto-value ratios were associated with higher housing prices and mortgage growth. For example, the required down payment on subprime mortgages in the United States was $2.7 \%$ in 2006 as housing prices peaked. ${ }^{(36)}$ During the GFC, counties with higher mortgage indebtedness (e.g., United Kingdom, United States, Netherlands, Ireland) recorded more serious declines in housing prices than those with lower indebtedness (e.g., France, Germany, Austria). (37)

Housing booms and busts directly affect the overall economy. The recent experiences in the United States, Spain, Ireland, and to a lesser extent the United Kingdom provide fresh examples of unsustainable housing booms that have turned into busts, with sizable out-put losses and crises in the banking sector and overall economy in some cases. ${ }^{(38)}$ The GFC is not an exceptional case. Reinhart and Rogoff show that the six major historical episodes of banking crises in advanced economies since the mid-1970s were associated with housing busts. ${ }^{39}$ ) This pattern can also be found in the emerging markets: for instance, the magnitude of housing price declines in the 1997 Asian financial crisis.

Although pre-crisis and in the early stage of the crisis, housing price movements were intimately linked with the size of the mortgage market, and housing busts were associated with economic stress, there was no positive correlation between the size of mortgage markets and overall economic stability. While Portugal, Italy, Ireland, Greece, and Spain (PIICS) were under the most economic stress in the GFC, there was substantial variation in the size of their mortgage markets. They were very small in Greece and Italy,

31. Veronica Warnock and Francis Warnock, "Market and Housing Finance," Journal of Housing Economics, No. 17, 2008, pp. 239-251.

32. IMF, "Global Financial Stability Report 2011," op. cit.

33. Dwight Jaffee, "the U.S. Subprime Mortgage Crisis: Issues Raised and Lessons Learned," op. cit.

34. IMF, "Global Financial Stability Report 2011," op. cit.

35. Franklin Allen, James Barth, and Glenn Yago, "Financial Innovations and the Stability of the Housing Market," National Institute Economic Review, Vol. 230, No. 1, 2014, p. 16

36. IMF, "Housing Finance and Financial Stability-Back to Basics," 2011, www.imf.org/external/ pubs/ft/gfsr/2011/01/pdf/chap3.pdf (accessed on 30 December 2014).

37. Hugo Priemus and Christine Whitehead, "Interactions between the Financial Crisis and National Housing Markets," Journal of Housing and the Built Environment, Vol. 29, No. 2, 2014, pp. 193200.

38. Giovanni Dell'Ariccia, Pau Rabanal, Christopher Crowe, and Deniz Igan, "Policies for Macro-financial Stability: Options to Deal with Real Estate Booms," IMF, 2011, www.imf.org/external/ pubs/cat/longres.aspx?sk=24600.0 (accessed on 30 December 2014).

39. Carmen Reinhart and Kenneth Rogoff, "The Aftermath of Financial Crises," NBER Working Paper No. 14656, January 2009, www.nber.org/papers/w14656 (accessed on 30 December 2014). 
average in Spain and Portugal, and large in Ireland (35\%, 23\%, 64\%, 66\%, and $87 \%$ respectively). ${ }^{(40)}$

The relationship also applies to China. Relaxing lending standards, as part of the stimulus package in 2008 initiated by the government to cope with the GFC, resulted in a big housing boom around 2010. Credit restrictions imposed in 2011 greatly constrained housing transactions in the next couple of years. The recent housing downturn in 2014 was mainly a result of the capital shortage in the banking system. As housing served as a pillar industry since the end of the 1990s, fluctuations in the housing market inevitably affected overall economic growth. The overall rise in the housing sector in the 1990s and $2000 \mathrm{~s}$ made a huge contribution to prosperous economic growth; the downturn in the housing market in 2014 was a main reason for declining GDP in 2014.

Overall, the mortgage markets in the selected economies and in China differ considerably along a number of dimensions (see Table 7). The Chinese mortgage market is relatively underdeveloped, largely because of the rudimentary development of the housing and financial sectors during its market transition. While housing finance in many economies focused on the consumption side, most of the real estate investment in China flowed to the supply sector in the 1990s, and it was not until the 2000s that China saw rapid growth in the mortgage market. Nevertheless, the size of the mortgage market today is still much smaller than in the case countries. Although fixed-interest-rate mortgages are popular in some countries, they are rare in China. China's central bank has managed to maintain a standard of minimum loan-to-value of $80 \%$, which helped avoid the phenomenon of underwater residential mortgages ${ }^{(41)}$ in China during the market downturn. Many advanced economies have integrated the mortgage sector into the capital market and have developed instruments to fund mortgages (e.g., covered bonds or MBS). However, a secondary market is not found in China. The mortgage markets in both the market economies and in China have seen a positive relationship between housing price movements and the size of mortgage market and between housing price movements and economic stability; however, there is no direct correlation between the size of the mortgage market and overall economy stability.

Government involvement in the mortgage sector is seen in both the market economies and China, but in different forms and degrees. The nature of housing necessitates a government role in mitigating or correcting undesirable market outcomes. Government involvement does not necessarily guarantee a stable housing market, however. The United States, a country with deep government involvement in the housing finance sector, experienced steep housing price declines during the crisis. Although its strong government involvement provided access to affordable mortgage financing, there is limited evidence that it boosted homeownership, made the system more efficient, or provided buffers against economic stress, and it might have exacerbated the amplitude of the recent boom-bust cycle. ${ }^{(42)}$ Ellis also claims that interest rate deductibility, combined with the lack of prepayment penalties, contributed to the growth of mortgage indebtedness in the United States. ${ }^{(43)}$ China has recorded deep government involvement in the mortgage market but in a different form (administrative measures and monetary policies). The five state-owned banks under strict supervision of the central bank dominate the mortgage market, reflecting a legacy of administrative controls and market mechanisms in the housing finance sector. This has led to an imbalanced housing structure between the ownership and rental sectors, and between public and social tenures. In contrast, the German government focused more on balanced housing development in the rental vs. ownership market. Consequently, its market proved more resilient in the GFC. The implication is that government involvement in the housing and mortgage sec- tors is necessary; the form of government involvement is more crucial for a sustainable housing finance system.

\section{Lessons for the development of mortgage finance in China}

This paper has answered the three questions raised in Section 1. First, the paper shows that downturns in the housing markets in some advanced countries around 2008 and in China in 2014 all derived from the financial sector but with different roots. The over-securitisation of mortgages in the United States accounted most for its housing decline and subsequent economic stress; however, the housing downturn in China is largely a result of the underdeveloped housing finance sector. While the IMF suggests that the securitisations of financial products aimed at spreading risk in the United States must return to basics, ${ }^{(44)}$ one of the most promising remedies for the problem of housing price decline in China is to further develop the housing finance sector through more product offerings and capital access alternatives for the housing and banking sectors. Moreover, the lesson from the PIIGS is that problems in a small mortgage market can also result in national economic stress. In this regard, it is wrong to think that China's small mortgage market will not threaten the financial and even the overall economy.

Second, the international experiences imply the significance of regulatory and legal frameworks for a well-functioning mortgage market. Following the famous slogan of "crossing the river by touching the stones underneath," China has adopted a trial-first approach in some phased reforms in the economic transition over the past decades, in which regulatory and legal frameworks are developed based on the experiences generated from the trials. However, this approach might not be applicable to the mortgage finance sector, which is significant for not only the economic sector, but also for the lives of individual citizens. Mortgage systems need to be supported by explicit legal institutions and instruments and to be developed in a manner that enhances economic efficiency while ensuring a sense of social fairness. In the absence of a well-functioning legal system and mature primary mortgage market, it is too early to develop a secondary mortgage market. China needs to make more effort to improve diversity in the primary market before establishing a secondary market.

Third, housing in market economies by its nature inevitably has two types of demand, namely shelter and investment. In the United States, housing was treated as a financial derivative manipulated by elites or financial whizzes, and triggered the GFC around 2008. In China, housing development has been an engine to sustain economic growth since the end 1990s; however, this has led to imbalances between the public and private sectors ${ }^{(45)}$ and ownership given priority over rental tenure. This paper indicates that

40. Franklin Allen, James Barth, and Clenn Yago, "Financial Innovations and the Stability of the Housing Market," art. cit.

41. Meaning that the mortgagers owe more on their mortgages than their houses are worth.

42. IMF, "Global Financial Stability Report 2011," 2011, op. cit.

43. Luci Ellis, "The Housing Meltdown:Why Did It Happen in the United States," Bank for International Settlements Working Paper No. 259, 2008, www.bis.org/publ/work259.htm (accessed on 30 December 2014).

44. IMF, "Clobal Financial Stability Report 2011," 2011, op. cit.

45. As of December 2010 , social housing represented $7-8 \%$ of the total housing inventory in China. Cf. Zhonghua renmin gongheguo zhufang he chengxiang jianshe bu (Ministry of Housing and Urban-rural Development), "'Shierwu' mo woguo chengzhen baozhang fang fugailü jiang da $20 \%$ yishang" (Increasing the Ratio of Social Housing to Total Urban Housing Inventory to $20 \%$ by the End of the $12^{\text {th }}$ Five-year Plan), 2011, http://www.mohurd.gov.cn/zxydt/201103/t201103 07_202754.html (accessed on 30 December 2014). 
homeownership promotion does not guarantee a stable housing market; for sustainable socio-economic development, housing should be treated as neither an economic engine as in China nor a financial derivative as in the United States. While many scholars today claim that housing should return to its basic as shelter in the United States, balancing the demand for housing as shelter and investment remains a major issue for China in its market transition.

It should be noted that the Western experiences provide a useful but limited reference for China. Housing finance brings together complex and multi-sectoral issues that are driven by constantly changing local features, such as a country's legal environment or culture, economic makeup, regulatory environment, and political system. ${ }^{(46)}$ While economy tends to be global, the factors of politics and society are localised. There is no one ideal mortgage instrument for a market; a robust mortgage market will have several different instruments that can be tailored to the varying needs of market players in different regions. China has a very different background from the market economies in terms of its political regime, governance ideology, economic status, and cultural and philosophical standpoints. Its strong government involvement in the socialist regime indicates that politic factors matter in the mortgage sector and that the housing and banking systems are not responsive to market incentives alone. This fundamental divergence implies that China should not adopt finance innovations developed in the Western systems wholesale; it needs to develop its own model for the development of the mortgage market based on the international experiences and its unique background.

I Zhou Zhihua is a research fellow at East Asian Institute, National University of Singapore.

4th Floor, Tower Block, 469A Bukit Timah Road, Singapore 259770 (eaizhouz@nus.edu.sg). 